\title{
Effects of Hypercapnia on Renal Nerve Activity
}

\author{
Machiko Shirahata, ${ }^{*}$ Takashi Nishino, ${ }^{*}$ Yoshiyuki Honda, ${ }^{* *}$ \\ Kazuto ITOH, ${ }^{* * *}$ and Toshihide YonezAwA* \\ *Department of Anesthesiology and **Department of Physiology, \\ Chiba University School of Medicine, Chiba, 280 Japan \\ ***Department of Anesthesiology, Chiba National Hospital, \\ Chiba, 260 Japan
}

\begin{abstract}
We investigated the response of renal nerve activity (RNA) to hypercapnia and assessed the contribution of the peripheral chemoreceptors to the response of RNA in anesthetized and artificially ventilated cats. RNA and arterial pressure were recorded at four levels of $P_{\mathrm{ET}_{\mathrm{CO}}}$ with hyperoxia in intact and in peripheral chemoreceptor denervated cats. In intact cats, RNA increased progressively with increasing $P \mathrm{ET}_{\mathrm{CO}_{2}}$, while no consistent change in arterial pressure was observed. In peripheral chemoreceptor denervated cats, the response of RNA to increasing $P_{\mathrm{ET}_{\mathrm{CO}_{2}}}$ was totally abolished. These results suggest that the peripheral chemoreceptors play an important role in increasing RNA during hypercapnia.
\end{abstract}

Key words: hypercapnia, peripheral chemoreceptors, renal nerve activity.

Blood carbon dioxide tension markedly affects cardiovascular dynamics. Hypercapnia causes myocardial depression (MCELROY et al., 1958; NEJAD and OGDEN, 1967) and dilatation of peripheral vessels (DAUGHERTY et al., 1967). In addition to these direct actions, changes in sympathetic nerve activity caused by hypercapnia modify the total hemodynamic responses. It is known that the change in sympathetic nerve activity during hypercapnia differs from organ to organ. For example, the resistance vessels in the skeletal muscle and splanchnic bed constrict during hypercapnia, whereas cutaneous vessels dilate (MOHAMED and BEAN, 1951; Pelletier and Shepherd, 1972; Pelletier, 1972). In renal hemodynamics, renal blood flow decreases (StONe et al., 1958; BerSENTES and Simmons, 1967; NORMAN et al., 1970; FABER et al., 1976; ANDERSON et al., 1983) during hypercapnia, and renal nerve activity might play an important role in decreasing renal blood flow (StONe et al., 1958; NoRMAn et al., 1970; ANDERSON et al., 1983). However, there have been few studies in which renal nerve activity has been directly

Received for publication October 30, 1984

白幡犋知子, 西野 卓, 本田良行, 伊東和人, 米澤利英 
recorded. In this study, we investigated the response of renal nerve activity to hypercapnia and assessed the contribution of the peripheral chemoreceptors to that response.

\section{MATERIALS AND METHODS}

Twenty-one cats weighing $2.2-4.1 \mathrm{~kg}$ were used in this study. They were anesthetized with $\alpha$-chloralose $(60-80 \mathrm{mg} / \mathrm{kg})$ administered intraperitoneally. The trachea was cannulated low in the neck. The right femoral artery was cannulated for the measurement of arterial blood pressure. The right femoral vein was also cannulated. The rectal temperature of the animals was maintained at about $38^{\circ} \mathrm{C}$ with a heating lamp. The method of renal nerve dissection was similar to that described in a previous paper (ShIRAHATA et al., 1983). Renal nerve activity (RNA) was recorded from the cut central end of the multifiber strands with bipolar silver-silver chloride electrodes. The nerve signal was amplified by a preamplifier with a high cutoff frequency of $3,000 \mathrm{~Hz}$ and a low cutoff frequency of $100 \mathrm{~Hz}$. The amplified signal was monitored with an oscilloscope. The signal was rectified with a full-wave rectifier circuit and then integrated. The integrator was reset at $5 \mathrm{sec}$ intervals. After surgical preparation, the animals were paralyzed with pancuronium bromide $(0.2 \mathrm{mg} / \mathrm{kg}$, i.v. $)$ and artificially ventilated.

To obtain various levels of $\mathrm{CO}_{2}$ partial pressure, the inspired gas was controlled

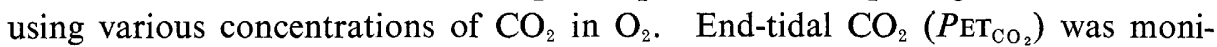
tored continuously with an infrared $\mathrm{CO}_{2}$ analyzer (Medical Electronics Laboratory, RAS-41).

Experimental procedure. In one series of experiments, the responses of RNA to $\mathrm{CO}_{2}$ were investigated in 12 cats. Inspired $P_{\mathrm{CO}_{2}}$ was raised in three steps under hyperoxia $\left(\mathrm{PET}_{\mathrm{O}_{2}}>550 \mathrm{mmHg}\right.$ ). RNA, integrated RNA (IRNA), arterial pressure (AP), and $\mathrm{PET}_{\mathrm{CO}_{2}}$ were recorded on a photorecorder (Yokogawa, Type 2915).

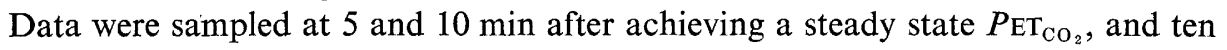
sets of values for IRNA and AP were read from their tracing every $5 \mathrm{sec}$ and averaged.

In another series of experiments, the contributions of carotid and aortic chemoreceptors to the response of RNA to changing $P \mathrm{ET}_{\mathrm{CO}_{2}}$ were assessed in 14 cats. In 7 cats, the carotid sinus nerves were surgically denervated, and the response of RNA to $\mathrm{CO}_{2}$ was observed. Then, the aortic nerves were sectioned and the response of RNA to $\mathrm{CO}_{2}$ were observed again. In the other 7 cats, the order of the denervation was changed; initially the aortic nerves were sectioned and the denervation of the carotid sinus nerves followed. Experimental procedures were the same as those in the cats with intact nerves.

All data were reported as mean values \pm S.E.M. Statistical significance of the results was determined by the Student's $t$-test for paired data. $p<0.05$ was considered to be statistically significant. 


\section{RESULTS}

Figure 1 shows an original recording of changes in renal nerve activity (RNA) and arterial pressure (AP) in response to increase in $P_{\mathrm{ET}_{\mathrm{CO}_{2}}}$ in intact cats. Figure $1 \mathrm{~A}$ is control, and $\mathrm{PET}_{\mathrm{CO}_{2}}$ is $28 \mathrm{mmHg}$. Each pair shows the recordings at 5 and $10 \mathrm{~min}$. When $\mathrm{PET}_{\mathrm{CO}_{2}}$ increased, changes in AP were variable. On the other

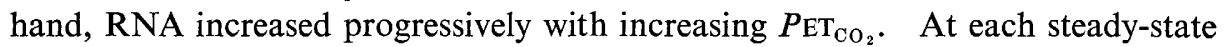
level of $P_{\mathrm{ET}_{\mathrm{CO}_{2}}}$, RNA was stable and similar at 5 and $10 \mathrm{~min}$. In all other cats, responses in RNA and AP to increasing $P_{\mathrm{ET}_{\mathrm{CO}_{2}}}$ were similar; RNA progressively increased with increasing $P \mathrm{ET}_{\mathrm{CO}_{2}}$, while AP showed no consistent change.

The effects of increasing the levels of $\mathrm{PET}_{\mathrm{CO}_{2}}$ on RNA and AP are summarized in Fig. 2. The left panel shows changes in integrated renal nerve activity (IRNA) and mean arterial pressure (MAP) at 5 min after $P \mathrm{ET}_{\mathrm{CO}_{2}}$ reached steady state. The values are expressed as a percent of each value at $10 \mathrm{~min}$ after $\mathrm{PET}_{\mathrm{CO}_{2}}$ level reached about $29 \mathrm{mmHg}$ in each experiment. Although there were no significant changes in the mean arterial pressure values, integrated renal nerve activity increased to 112,135 , and $145 \%$ at $P_{\mathrm{ET}_{\mathrm{CO}_{2}}}$ of 43,57 , and $71 \mathrm{mmHg}$, respectivity. The values at $P_{\mathrm{ET}_{\mathrm{CO}}}$ of 57 and $71 \mathrm{mmHg}$ were significantly greater than the value at $P_{\mathrm{ET}_{\mathrm{CO}_{2}}}$ of $29 \mathrm{mmHg}$. At $10 \mathrm{~min}$ after $P_{\mathrm{ET}_{\mathrm{CO}_{2}}}$ reached steady state (the right panel), the values of IRNA at $P_{\mathrm{ET}_{\mathrm{CO}_{2}}}$ of 43,57 , and $72 \mathrm{mmHg}$ were significantly greater than the value of IRNA at $P_{\mathrm{ET}_{\mathrm{CO}}}$ of $29 \mathrm{mmHg}$.

After the carotid sinus nerves were denervated, an increase in RNA with increasing $P_{\mathrm{ET}_{\mathrm{CO}}}$ was also observed in 6 out of 7 cats, although the degree of

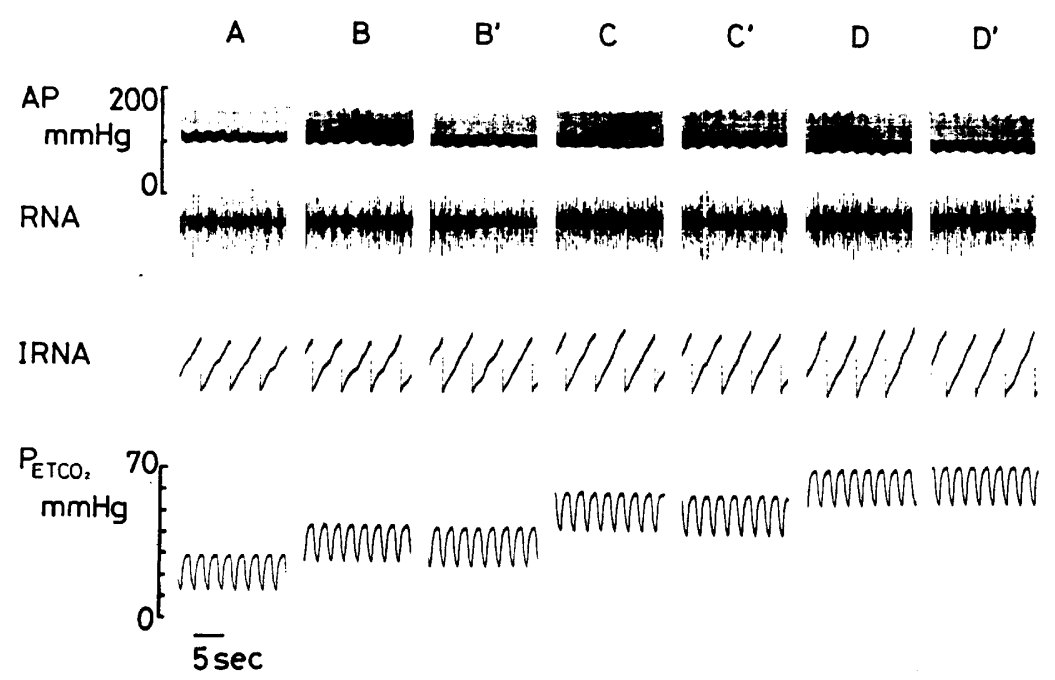

Fig. 1. An original recording of arterial pressure (AP), renal nerve activity (RNA), integrated renal nerve activity (IRNA), and $P_{\mathrm{ET}_{\mathrm{CO}_{2}}}$. A is control. Each pair shows the recordings at 5 and $10 \mathrm{~min}$ after $P_{\mathrm{ET}_{\mathrm{CO}}}$ reached steady state. 


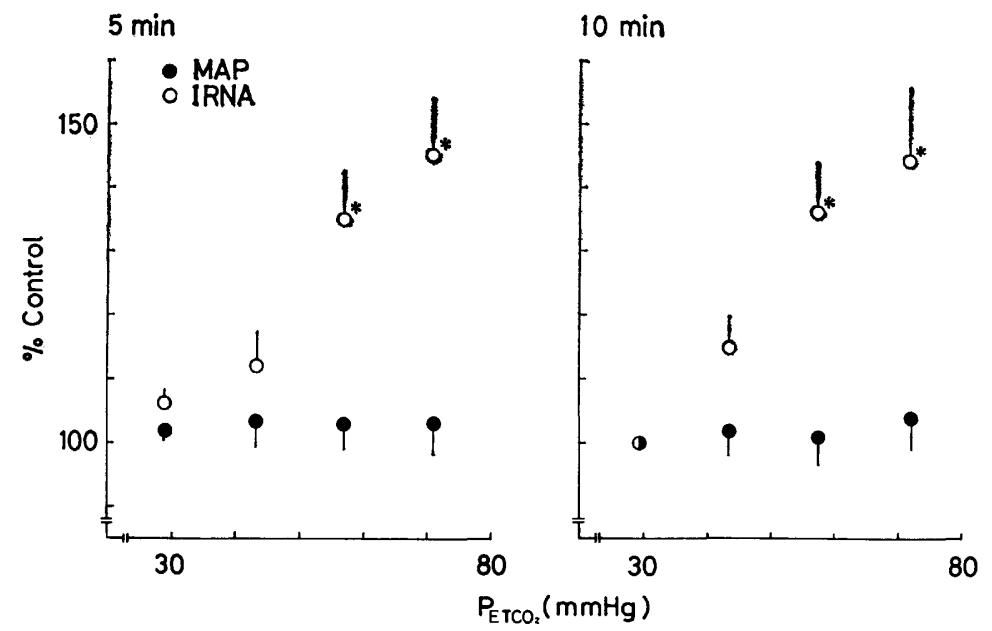

Fig. 2. The effects of $P_{\mathrm{ET}_{\mathrm{CO}}}$ on integrated renal nerve activity (hollow circles) and mean arterial pressure (solid circles). They are expressed as percent of control values which are the values at $10 \mathrm{~min}$ after $P_{\mathrm{ET}_{\mathrm{CO}}}$ reached about $29 \mathrm{mmHg}$ in each experiment (mean \pm S.E.M.). Asterisks show values significantly different from control value $(p<0.05)$.

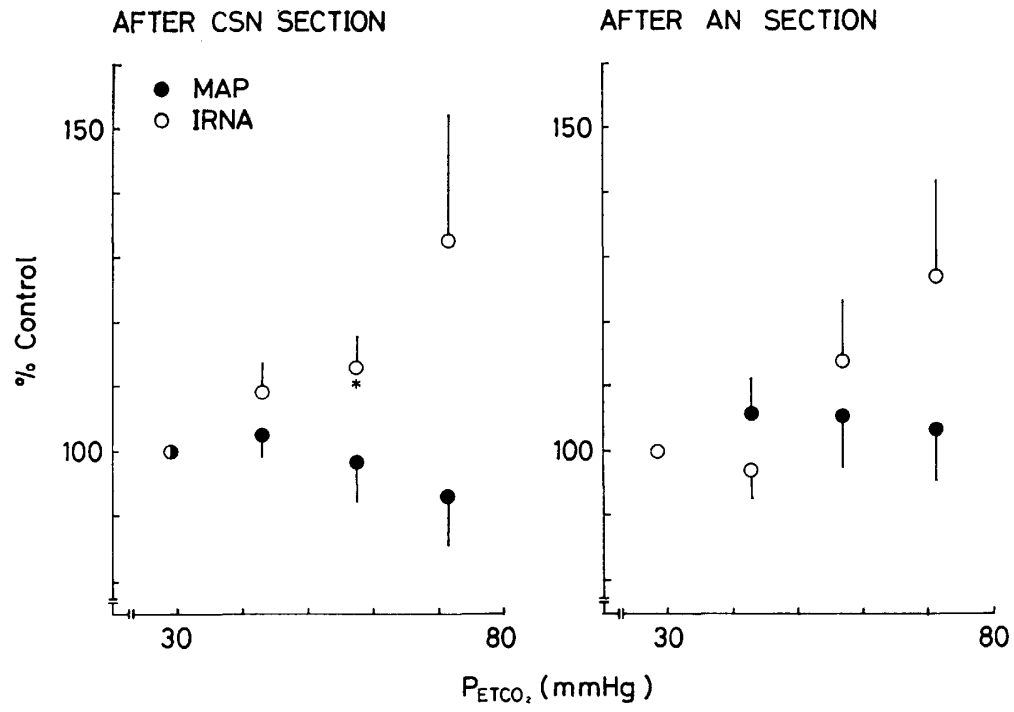

Fig. 3. The effects of $\mathrm{PET}_{\mathrm{CO}_{2}}$ on integrated renal nerve activity (hollow circles) and mean arterial pressure (solid circles) at $10 \mathrm{~min}$ after $P \mathrm{ET}_{\mathrm{CO}_{2}}$ reached steady state. Left panel shows the values after carotid sinus denervation (CSN), and right panel shows the values after aortic nerves section (AN). Each variable is expressed as percent of the control

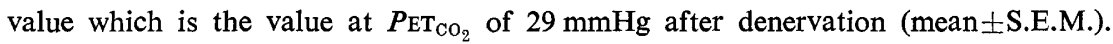
Asterisks show values significantly different from control value $(p<0.05)$. 
AFTER CSN \& AN SECTION

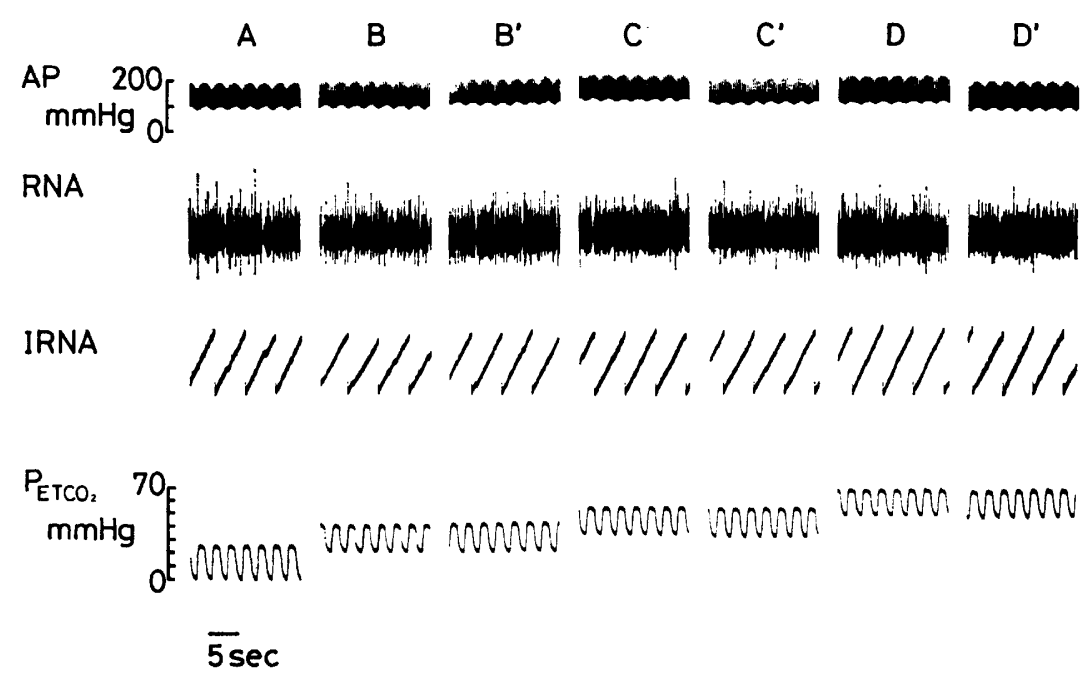

Fig. 4. A representative recording of artieral pressure (AP), renal nerve activity (RNA), integrated renal nerve activity (IRNA), and $\mathrm{PET}_{\mathrm{CO}_{2}}$ after sino-aortic (CSN and AN) denervation. A is control. Each pair shows the recordings at 5 and $10 \mathrm{~min}$ after $P_{\mathrm{ET}_{\mathrm{CO}_{2}}}$ reached steady state.

increase was lessened. AP change was variable in the carotid sinus denervated cats. On the other hand, in the aortic denervated cats changes in RNA were not consistent at $P_{\mathrm{ET}_{\mathrm{CO}_{2}}}$ of 43 and $57 \mathrm{mmHg}$. At $P_{\mathrm{ET}_{\mathrm{CO}_{2}}}$ of $72 \mathrm{mmHg}$, RNA increased in 5 out of 7 cats. AP also showed variable changes. In each denervated group, RNA at 5 and 10 min after $P_{\mathrm{ET}_{\mathrm{CO}}}$ reached steady state were similar, and Fig. 3 therefore shows only the results obtained after $10 \mathrm{~min}$. There were no significant differences between mean values for IRNA in carotid denervated and aortic denervated cats at each $P_{\mathrm{ET}_{\mathrm{CO}}}$ level.

In 11 cats both carotid and aortic nerves were sectioned. A representative recording is shown in Fig. 4. In these animals, like the response in nerve intact cats, AP change was variable. However, unlike the response in cats with intact nerves, little or no change was observed in RNA, inspite of increasing $P_{\mathrm{ET}_{\mathrm{CO}_{2}}}$. Mean values for MAP and IRNA at 5 and $10 \mathrm{~min}$ after $P_{\mathrm{ET}_{\mathrm{CO}_{2}}}$ reached steady state showed no statistically significant changes (Fig. 5).

\section{DISCUSSION}

We demonstrated in this study that renal nerve activity (RNA) increases with increasing $P_{\mathrm{ET}_{\mathrm{CO}}}$ when afferent input from the peripheral chemoreceptors is intact. In this study we observed the steady-state response of RNA to hypercapnia. 


\section{AFTER CSN \& AN SECTION}

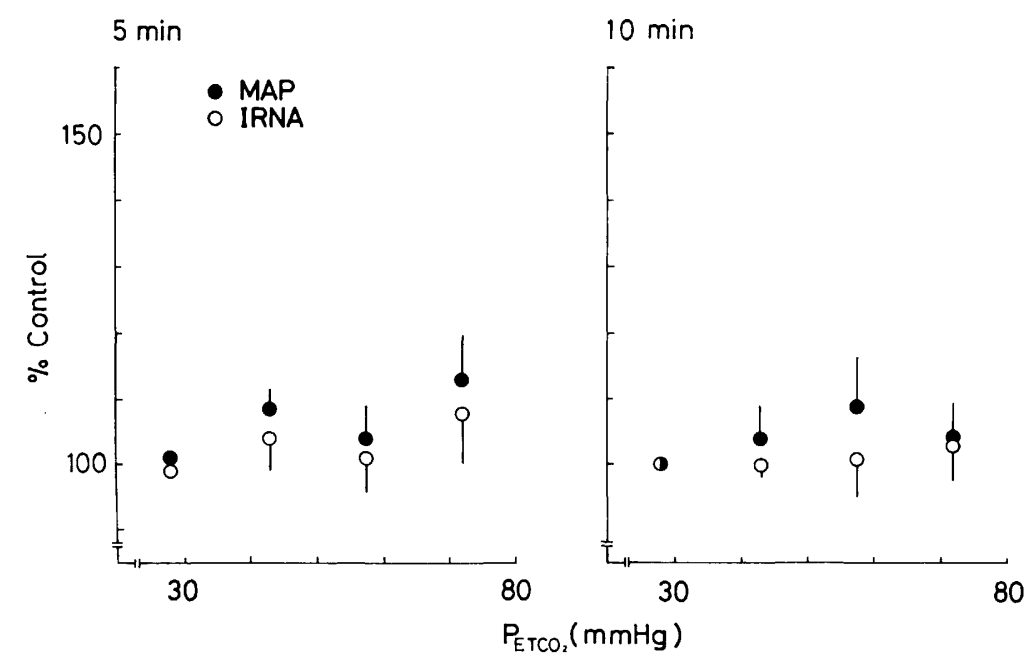

Fig. 5. Changes in integrated renal nerve activity (hollow circles) and mean arterial pressure (solid circles) with increasing $P_{\mathrm{ET}_{\mathrm{CO}_{2}}}$ after sino-aortic (CSN and $\mathrm{AN}$ ) denervation. Each variable is expressed as percent of control which is the value at $P_{\mathrm{ET}_{\mathrm{CO}_{2}}}$ of $29 \mathrm{mmHg}$ after denervation (mean \pm S.E.M.). Asterisks show values significantly different from control value $(p<0.05)$.

The degrees of RNA change at 5 and 10 min at each $P \mathrm{ET}_{\mathrm{CO}_{2}}$ level were similar both when the nerves were intact and denervated. These findings show that there may be little or no adaptation of RNA response to hypercapnia during the period we observed.

It is well known that RNA is reflxly influenced by several mechanisms. Increases in the carotid sinus or systemic arterial pressure inhibit RNA, whereas decreases in these pressures increase RNA via the baroreflex (KEZDI and GELLER, 1968; NINOMIYA and IRISAWA, 1969). Low pressure cardiopulmonary receptors also affect RNA; blood volume expansion or left atrial balloon inflation decreases RNA, and a decreases in blood volume increases RNA (CLEMENT et al., 1972; KARIM et al., 1972; Prosnitz and DibOnA, 1978). In this study, arterial pressure changes were variable and statistically insignificant. In addition, since blood loss during the surgical preparation was minimal, a remarkable volume change was unlikely during the course of the experiment. Therefore, it is unlikely that the increase in RNA observed in this study was caused mainly by the baroreflex or cardiopulmonary reflex.

We assessed the contribution of peripheral chemoreceptors to this response to RNA to hypercapnia by using denervation procedures. After both carotid sinus and aortic nerves were denervated, little or no change in RNA was observed in spite of increasing $P_{\mathrm{ET}_{\mathrm{CO}}}$. This finding suggests that peripheral chemoreceptors 
play an important role in increasing RNA during hypercapnia. In contrast to our observation, SIMON and RIEDEL (1975) showed that the response to hypercapnia in cardiac, intestinal, and cutaneous nerves was preserved after deafferentiation of peripheral chemoreceptors. Two possibilities might be considered with regard to the discrepancy between their results and ours. First, it may be due to the different levels of hypercapnia employed in our study and their study, since the degree of hypercapnia they used to stimulate central chemoreceptor is more severe than that we used. Second, there may be differences of sensitivity to hypercapnia among different populations of sympathetic nerves in the central nervous system.

It is difficult to assess the relative contributions of aortic and carotid chemoreceptors to RNA changes during hypercapnia in this experiment. Although increases in RNA with increasing $P_{\mathrm{ET}_{\mathrm{CO}_{2}}}$ were observed more consistently in carotid denervated cats. Previous reports showed conflicting results about the relative contributions of aortic and carotid chemoreceptors to cardiovascular changes. Comroe (1939) showed by using denervation techniques that stimulation of aortic bodies might play a more important role in producing arterial pressure responses than do carotid bodies. On the other hand, DALY and UNGAR (1966) used separate perfusion techniques and concluded that the relative contributions of carotid and aortic bodies are not significantly different. More detailed study should be performed to assess the relative contributions of aortic and carotid chemoreceptors to sympathetic nerve activity and cardiovascular dynamics.

It is known that renal nerves control renal blood flow, urinary sodium reabsorption, and secretion of renin, and thereby play an important role to regulate body fluids, the electrolyte balance, and arterial pressure (DiBONA, 1982). Several investigators reported that renal blood flow decreased during hypercapnia (STONE et al., 1958; Bersentes and Simmons, 1967; NormAn et al., 1970; FABER et al., 1976; ANDERSON et al., 1983) and this decrease was attenuated after renal denervation. Other studies showed that hypercapnia decreased urinary sodium excretion (ANDERSON et al., 1982) and increased renin secretion (FUJI and ZEHR, 1975; Morita, 1976; KurTZ and Zehr, 1978; StASZEWSKa-BARCZAK, 1978). These observations together with our present results suggest that an increase in RNA during hypercapnia might contribute to maintain arterial blood pressure by counteracting the direct vasodilating effect of hypercapnia and by exerting antinatriuretic and antidiuretic actions.

\section{REFERENCES}

Anderson, R. J., Henrich, W. L., Gross, P. A., and Dillingham, M. A. (1982) Role of renal nerves, angiotensin II and prostaglandins in the antinatriuretic response to acute hypercapnic acidosis in the dog. Circ. Res., 50: 294-300.

Anderson, R. J., Pluss, R. G., Pluss, W. T., Bell, J., and Zerbe, G. G. (1983) Effect of hypoxia and hypercapnic acidosis on renal autoregulation in the dog: Role of renal nerves. Clin. Sci., 65: 533-538.

Vol. 35, No. 3, 1985 
Bersentes, T. J. and Simmons, D. H. (1967) Effects of acute acidosis on renal hemodynamics. Am. J. Physiol., 212: 633-640.

Clement, D. L., Pelletier, C. L., and Shepherd, J. T. (1972) Role of vagal afferents in the control of renal sympathetic nerve activity in the rabbit. Circ. Res., 31: 824-830.

Comroe, J. H., Jr. (1939) The location and function of the chemoreceptors of the aorta. Am. J. Physiol., 127: 176-191.

DaLY, M. de B. and UnGaR, A. (1966) Comparison of the reflex responses elicited by stimulation of the separately perfused carotid and aortic body chemoreceptors in the dog. $J$. Physiol. (Lond.), 182: 379-403.

Daugherty, R. M., Jr., Scott, J. B. Dabney, J. M., and Haddy, F. J. (1967) Local effects of $\mathrm{O}_{2}$ and $\mathrm{CO}_{2}$ on limb, renal and coronary vascular resistances. Am. J. Physiol., 213: 11021110.

Dibona, G. F., (1982) The function of the renal nerves. Rev. Physiol. Biochem. Pharmacol., 94: 75-181.

Faber, M. O., Szwed, J. J., Dowell, A. R., and Strawbridge, R. A. (1976) The acute effects of respiratory and metabolic acidosis on renal function in dog. Clin. Sci. Mol. Med., 50: $165-169$.

FUJII, H. and ZeHR, J. E. (1975) The effects of respiratory acidosis on plasma renin activity in the dog. Jpn. Circ. J., 39: 1115-1121.

Karim, F., Kidd, C., Malpus, C. M., and Penna, P. E. (1972) The effects of stimulation of the left atrial receptors on sympathetic efferent nerve activity. J. Physiol. (Lond.), 226: 243260.

KeZDI, P. and Geller, E. (1968) Baroreceptor control of postganglionic sympathetic nerve discharge. Am. J. Physiol., 214: 427-435.

KURTZ, K. D. and ZEHR, J. E. (1978) Mechanisms of enhanced renin secretion during $\mathrm{CO}_{2}$ retention in dogs. Am. J. Physiol., 234: H573-H581.

McElroy, W. T., Gerdes, A. J., and Brown, E. B., Jr. (1958) Effects of $\mathrm{CO}_{2}$, bicarbonate and $\mathrm{pH}$ on the performance of isolated perfused guinea pig hearts. Am. J. Physiol., 195: 412416.

Mohamed, M. S. and BeAN, J. W. (1951) Local and general alterations of blood $\mathrm{CO}_{2}$ and influence of intestinal motility in regulation of intestinal blood flow. Am. J. Physiol., 167: 413-425.

Morita, T. (1976) Plasma renin activity in acute respiratory acidosis. Jpn. Circ. J., 40: 123126.

NejAD, N. S. and OGden, E. (1967) Effect of blood $\mathrm{pH}$ and $\mathrm{CO}_{2}$ tension on performance of the heart-lung preparation. Proc. Soc. Exp. Biol. Med., 126: 771-776.

NinomiYa, I. and IrISAWA, H. (1969) Summation of baroceptor reflex effects on sympathetic nerve activities. Am. J. Physiol., 216: 1330-1336.

Norman, J. N., Macintyre, J., Shearer, J. R., Craigan, I. M., and Smith, G. (1970) Effect of carbon dioxide on renal blood flow. Am. J. Physiol., 219: 672-676.

Pelletier, C. L. (1972) Circulatory responses to graded stimulation of the carotid chemoreceptors in the dog. Circ. Res., 31: 431-443.

Pelletier, C. L. and Shepherd, J. T. (1972) Venous responses to stimulation of carotid chemoreceptors by hypoxia and hypercapnia. Am. J. Physiol., 223: 97-103.

Prosnitz, E. H. and Dibona, G. F. (1978) Effect of decreased renal sympathetic nerve activity on renal tubular sodium reabsorption. Am. J. Physiol., 235: F557-F563.

Shirahata, M., OKadA, Y., and NinOMIYA, I. (1983) Effects of ketamine on renal nerve activity, arterial pressure and heart rate in rats. Jpn. J. Physiol., 33: 391-401.

SIMON, E. and RIEDEL, W. (1975) Diversity of regional sympathetic outflow in integrative cardiovascular control: Patterns and mechanisms. Brain Res., 87: 323-333. 
Staszewska-BarczaK, J. (1978) Participation of the sympathetic and the renin-angiotensin systems in blood pressure control during hypercapnia in the anesthetized dog. Eur. $J$. Pharmacol., 49: 441-444.

Stone, J. E., Wells, J., Draper, W. B., and Whitehead, R. W. (1958) Changes in renal blood flow in dogs during the inhalation of 30\% carbon dioxide. Am. J. Physiol., 194: 115-119. 